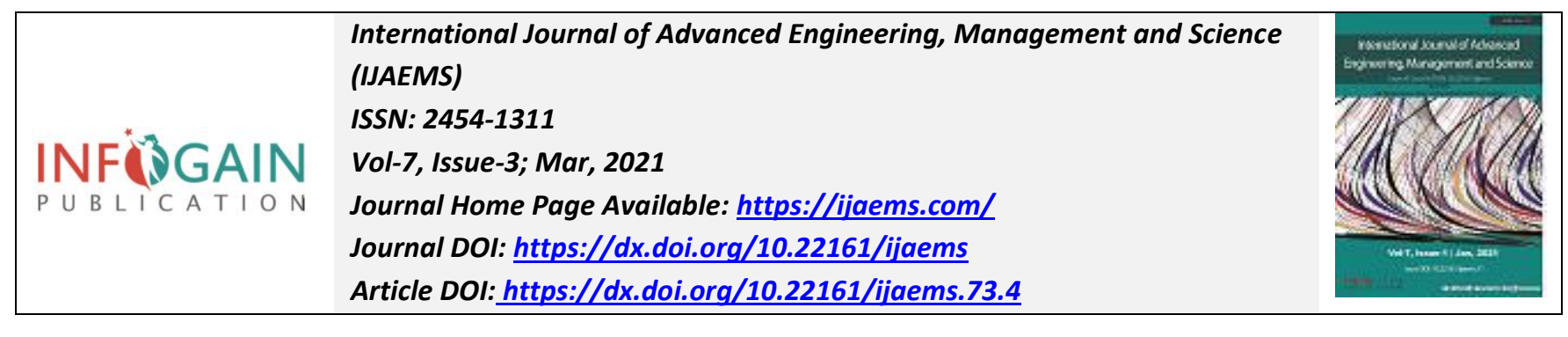

\title{
Mathematical Ability, Level of Science Misconceptions, and Science Performance of First-Year College Students
}

\author{
Princess Lydia S. Fuentes
}

Capiz State University, Dayao Satellite College, Philippines

Received: 01 Dec 2020; Received in revised form: 09 Feb 2021; Accepted: 25 Feb 2021; Available online: 11 Mar 2021

(C)2021 The Author(s). Published by Infogain Publication. This is an open access article under the CC BY license

(https://creativecommons.org/licenses/by/4.0/).

\begin{abstract}
This survey-correlational research aimed to ascertain the mathematical ability, level of science misconceptions, and science performance of 71 first- year college students of Capiz State University, Dayao Satellite College during the first semester of the academic year 2016-2017. Researcher-made test questionnaires and the revised American Association for the Advancement of Science Assessment Questionnaire instrument were used. In general, the respondents are mathematical "fairly able" $(M=29.15, S D=4.087)$. In particular, out of 71 respondents, 73\% are "fairly able", 24\% are "able" and only 3\% are "highly able". Respondents level of science misconceptions are "moderately high/low" $(M=28.83, S D=3.179)$ with $35 \%$ are with a "low" level of misconceptions and 65\% are with a "moderately high or low" level of science misconceptions. As a whole, respondents have "satisfactory" performance in science $(M=26.68, S D=3.179)$. Particularly, 89\% have "satisfactory" performance, 7\% with "very satisfactory" performance and only 4\% have "poor" performance in science. Inferential data analysis revealed that there is a significant difference in the science performance of the respondents when grouped according to their mathematical ability $(F(2,68)=111.463, p<0.05)$. The science performance differed significantly among the mathematical "highly able", "able", and the mathematical "fairly able" students. Also, results showed that there is a significant difference in the science performance when grouped by the level of science misconceptions. Furthermore, data revealed that students' performance in science is significantly related to their mathematical ability $(r=0.334, p<0.01)$ and level of science misconceptions $(r=1.000, p<0.01)$. Respondents' mathematical ability and level of science misconceptions are factors affecting science performance.
\end{abstract}

Keywords - mathematical ability, science misconceptions, science performance

\section{INTRODUCTION}

The development of human capacity in science and technology has been on the agenda of almost all developing countries over the past few decades including the Philippines. The education system is on track in revising and improving the current science education program to meet the highly competitive demand of society. Since the growth of science and technology contributes to the progress of a certain country particularly in socioeconomic development. Science education of the Philippines aims to develop scientific literacy among students that will prepare them to be informed and participative citizens of the country who can make judgments and decisions regarding applications of science and technology as a form of human knowledge in different aspects of the society such as in health and in our environment ( $\mathrm{K}$ to 12 Curriculum Guide Science, 2012).

It is being said that mathematics is the language of science and is considered as the training ground for analytical, systematic, and critical thinking. The understanding of Mathematics is vital in reporting results, experimental data, and explanation behind the concept of nature. 
Another interesting part of the science teaching and learning process is the beliefs of students on certain scientific principles and concepts. Concepts include the ideas, objects, or events that help us understand and interpret the world around us (Eggen and Kauchak, 2004 as cited by Thompson and Louge, 2006) while misconception can be described as ideas that may be rooted from a personal experience, preconceived notions, nonscientific beliefs, mixed conceptions, conceptual misunderstanding and a result of an incorrect or insufficient explanation (Hanuscin, 2007). It was observed that many students may have science misconceptions about the concepts of weight and mass, heat and temperature, endothermic and exothermic reactions, objects' motion specifically the free falling bodies, photosynthesis and respiration. What is more critical in addressing science misconceptions is that students' conceptions do not change after instruction and may be developed through time. It seems obvious to Robelen (2013) that teachers need to understand the lesson content that they are trying to convey to students. However, study finds that what is critical to improved science learning is that teachers are unaware of the common misconceptions students have.

As observed, what may hinder students to fully understand science concepts is their poor idea or background of mathematics from elementary and secondary years. They may lack the ability to interpret science problems into equations and solve them using accurate mathematical principles. Thus, students should have strong scientific concepts and mathematical backgrounds to develop the problem- solving and analytical skills in science learning.

\section{OBJECTIVES OF THE STUDY}

This study aimed to ascertain the mathematical ability, level of science misconceptions and science performance of first-year college students of Capiz State University, Dayao, Satellite College of academic year 2016- 2017.

Specifically, the study sought to answer the following:

1. What is the mathematical ability of first-year college students?

2. What is the level of science misconception of first-year college students?

3. What is the science performance of first-year college students?

4. Is there a significant difference in the science performance of first-year college students when they are grouped according to their mathematical ability?
5. Is there a significant difference in the science performance of first-year college students when they are grouped according to their level of science misconceptions?

6. Are there significant relationships among mathematical ability, level of science misconceptions and performance?

In view of the aforementioned stated problems, the following hypotheses were forwarded:

1. There is no significant difference in science performance of first-year college students when they are grouped according to their mathematical ability.

2. There is no significant difference in science performance of first-year college students when they are grouped according to their level of science misconceptions.

3. There are no significant relationships among mathematical ability, level of science misconceptions, and performance.

\section{THEORETICAL BACKGROUND AND MODEL}

This study was anchored on the Theory of Constructivism of Piaget (1940) and Bruner (1960). Piaget suggests that children search for meaning as they interact with the world around them and use such experiences to test and modify existing schemas (Eggen and Kauchak, 2004 as cited by Chavan, Rajendra and Patankar, 2016) while Bruner as influenced by Piaget holds that learning is an active and knowledge building process that includes the facets of selection, transformation, decision making, generating hypotheses, and making meaning from information and experiences. Thus, Bruner emphasized that this process provides students the avenue to construct new concepts based on existing knowledge most likely when there is an absence of complete and accurate schema.

In this study, mathematical ability and level of science misconceptions are considered as the independent variables while science performance as the dependent variable.

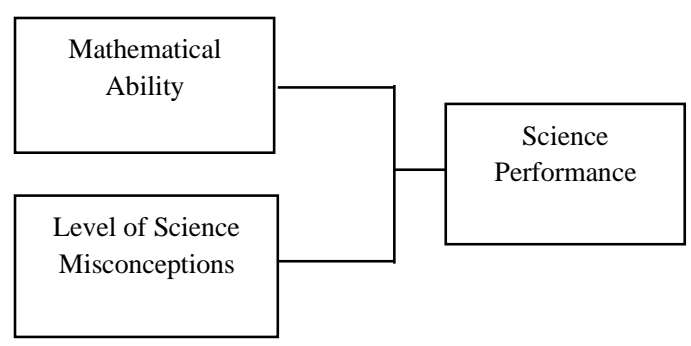

Fig.1: Conceptual Map 


\section{METHODOLOGY}

This survey-correlational research was conducted to determine the science performance of First-Year College Students of Capiz State University, Dayao Satellite College based on their mathematical ability and level of science misconceptions.

The participants of this study were the seventy-one (71) first-year college students randomly selected from BS Criminology (46) and BS Fishery (25) of the academic year 2016-2017. The Cochran formula was used in the computation of the sample size.

Researcher-made tests for mathematical ability and science performance, and the revised American Association for the Advancement of Science (AAAS) Assessment Questionnaire 2013 for the level of science misconceptions instruments were used. Prior to the conduct of the study, the Mathematical Ability and Science Performance Test had undergone face and content validation and was pilot tested among thirty (30) first-year students who are not part of the sample group and the results of was used for item analysis.

The statistical analyses used were mean, standard deviation, t-test for independent samples, Analysis of Variance (ANOVA), and Pearson $r$.

\section{RESULTS AND DISCUSSION}

This section presents the descriptive and inferential data and their respective analysis and interpretation.

\subsection{Mathematical Ability}

Table 1 presents the data on the mathematical ability of first-year college students. Data show that first-year students, in general are mathematical "fairly able" $(\mathrm{M}=29.15, \quad \mathrm{SD}=4.087)$. In particular, out of 71 respondents, $73 \%$ are "fairly able", 24\% are "able" and only $3 \%$ are "highly able".

Table 1 Mathematical Ability of First-Year College Students

\begin{tabular}{ccc}
\hline $\begin{array}{l}\text { Mathematical Ability } \\
\text { Mean=29.15, } S D=4.087\end{array}$ & $\mathrm{~F}$ & $\%$ \\
\hline \hline Highly Able $(41.00-50.00)$ & 2 & 3.0 \\
Able $(31.00-40.00)$ & 17 & 24.0 \\
Fairly Able $(21.00-30.00)$ & 52 & 73.0 \\
\hline Total & \multicolumn{3}{c}{71} & 100.0 \\
\hline Scale & \multicolumn{3}{l}{ Description } \\
$41.0-50.0$ & \multicolumn{3}{l}{ Highly Able } \\
$31.0-40.0$ & Able
\end{tabular}

$$
\begin{array}{ll}
21.0-30.0 & \text { Fairly Able } \\
11.0-20.0 & \text { Less Able } \\
0.00-10.0 & \text { Least Able }
\end{array}
$$

Mathematically "able" students are competent in that they have learned and acquired the basic mathematical knowledge and skills necessary in understanding mathematical concepts.

The result indicates that students acquired basic skills in mathematics but others do not know how to apply these skills in problem solving and analysis. This is visible in the actual teaching-learning process in which students acquire the four basic arithmetic skills and may get the correct answer but when asked to solve word problems they tend to give an incorrect one.

Furthermore, results revealed that students are 'mathematically able' in identifying types of fraction but 'mathematically fairly able' in analyzing Venn diagrams. It shows that students are poor in mathematical analysis that involves building and applying abstract, and logically connected networks of mathematical ideas. The need for knowledge in mathematics is certainly inevitable because the trouble of students in mathematics may lie in their deficiency in mathematical background.

\subsection{Level of Science Misconceptions}

Table 2 Level of Science Misconceptions of First Year College Students

\begin{tabular}{lcc}
\hline $\begin{array}{l}\text { Science Misconceptions } \\
\text { Mean=28.83, SD=3.291 }\end{array}$ & $\mathrm{f}$ & \multicolumn{1}{l}{$\%$} \\
\hline \hline Low (31.0-40.0) & 25 & 35.0 \\
Moderately High/Low (21.0-30) & 46 & 65.0 \\
\hline Total & 71 & 100.0 \\
\hline
\end{tabular}

Table 2 presents the data on the level of science misconceptions of first-year college students. Data show that in general students' level of misconceptions are "moderately high/low" $(\mathrm{M}=28.83, \quad \mathrm{SD}=3.291)$. More particularly, of the 71 students, $35 \%$ are with a "low" level of misconceptions and $65 \%$ are with a "moderately high or low" level of science misconceptions.

\section{Scale}

$$
\begin{aligned}
& 41.0-50.0 \\
& 31.0-40.0 \\
& 21.0-30.0 \\
& 11.0-20.0 \\
& 0.00-10.0
\end{aligned}
$$

Description Very Low Low Moderately High/Low High Very High 
In addition, students have a misconception on how the process of condensation works. However, results revealed that the students have 'low' misconception on the topic of temperature. The result of having a low level of misconceptions of students implies that they learned correct concepts but still have some incorrect beliefs or ideas in science on different states of matter, plant cells, zoology, motion and weather, and climate. Also, results indicate that some students acquired prior knowledge about the lesson or others may have an incorrect notion on how things work or having doubt, inappropriate ideas, misunderstanding and misinterpretations of facts. The result indicates that there is an obvious connotation of wrong ideas or incorrectly assimilated conceptions. Students hold still with their erroneous ideas that may lead to confusion and conflict. But the researcher believed that this could be corrected by providing appropriate schema in the learning process.

\subsection{Science Performance}

Presented in Table 3 is the data collected on the science performance test of first-year college students. Data revealed that the respondents have "satisfactory" performance in science $(\mathrm{M}=26.68, \quad \mathrm{SD}=3.179)$. Particularly, $89 \%$ of 71 students have "satisfactory" performance, $7 \%$ with "very satisfactory" performance and only $4 \%$ have "poor" performance in science, implying that respondents are knowledgeable about the different areas in science incorporated from the secondary science curriculum.

Table 3 Science Performance of First Year College Students

\begin{tabular}{lrr}
\hline Science Performance & & \\
Mean=26.68, SD=3.179 & $\mathrm{f}$ & \multicolumn{1}{c}{$\%$} \\
\hline \hline Very satisfactory (31.0.-40.0) & 5 & 7.0 \\
Satisfactory (21.0-30.0) & 63 & 89.0 \\
Poor (11.0-20.0) & 3 & 4.0 \\
\hline Total & 71 & 100.0 \\
\hline
\end{tabular}

Furthermore, results revealed that students perform 'satisfactorily' in distinguishing plant cells from animal cells but perform 'poorly' in the topic of the process of human reproduction. Results signify that students perform satisfactorily in science but not very satisfactorily, indicating that students only knew the basic concepts and they have difficulty in answering complex questions and problems.

\subsection{Difference in the Science Performance Among} Mathematical Abilities

The disciplines of mathematics and science are very different. However, science depends upon the certainty of mathematics to lend validity to its results, while mathematics relies upon science to provide real-life scenarios or events due to its abstract concepts to concrete applications. One needs to learn and possess good mathematical skills to perform well in science in which problem-solving, analysis of results, and interpreting numerical values are all incorporated. The students' lack of understanding of necessary mathematical concepts and representation may be the basic hindrance why some students cannot perform well in a related subject such as

Table 4 ANOVA of Science Performance

Among Mathematical Ability

\begin{tabular}{lccccc}
\hline $\begin{array}{l}\text { Source of } \\
\text { Variance }\end{array}$ & SS & df & MS & F & Sig. \\
\hline \hline $\begin{array}{l}\text { Between } \\
\text { Groups }\end{array}$ & 895.988 & 2 & 447.994 & 111.463 & $.000^{*}$ \\
Within & 273.308 & 68 & 4.019 & & \\
Groups & & & & & \\
Total & 1169.296 & 70 & & & \\
\hline
\end{tabular}

science.

*Significant @ 5\% level of significance

Table 4 presents the ANOVA results on the science performance of first year college students among their different mathematical abilities. Results show that students' science performance significantly differed $[\mathrm{F}(2,68)=111.463, \mathrm{p}<0.05]$ with their mathematical abilities. In addition, the post hoc Tukey HSD results also revealed that the science performance of students differed significantly among the mathematically "highly able", "able" and the mathematically "fairly able" students.

Consequently, the null hypothesis which states that there is no significant difference in science performance of students when they are grouped according to their mathematical ability is hereby rejected.

5.5 Difference in the Science Performance

\section{Considering Levels of Science Misconceptions}

Table 5 presents the t-Test of Science Performance of firstyear college students considering the levels of science misconceptions. Results showed that there is a significant difference in students' level of misconception in relation to their science performance. This implies that students' understanding either preconceived notion or ideas gained from observation and experience greatly affect their 
performance. It is evident that if students learned incorrect information, or did not fully understand a lesson in previous classes, they may have trouble learning new topics. On the other hand, students who learned and understand correct information have a better chance of success learning new lessons.

Table 5 t-Test of Science Performance Considering Levels of Science Misconceptions

\begin{tabular}{lccc}
\hline & & $\begin{array}{c}\text { Mathematical } \\
\text { Ability }\end{array}$ & $\begin{array}{c}\text { Science } \\
\text { Misconceptions }\end{array}$ \\
\hline \hline $\begin{array}{l}\text { Science } \\
\text { Performance }\end{array}$ & $\mathrm{r}$ & $.556^{*}$ & $-.488^{*}$ \\
& $\mathrm{Sig}$ & .000 & .000 \\
& $\mathrm{~N}$ & 146 & 146 \\
Mathematical & $\mathrm{r}$ & & \\
Ability & & & $-.545^{*}$ \\
& $\mathrm{Sig}$ & & .000 \\
& $\mathrm{~N}$ & & 146 \\
\hline
\end{tabular}

*Significant @ 5\% level of significance

Therefore, the null hypothesis which states that there is no significant difference in science performance of firstyear college students when grouped according to their level of science misconceptions is hereby rejected.

\subsection{Relationship of Science Performance, Mathematical Ability and Level of Science Misconceptions}

Mathematical ability and science misconceptions are factors affecting students' science performance. Results show that mathematical ability and level of science misconceptions are also significantly related $(r=0.334$, $\mathrm{p}<0.01)$. Since they are significantly related to one another it is noted that with the right science concepts and ideas together with strong mathematical background students will perform very satisfactorily in science. Results show that the two variables are factors affecting science performance.

Table 6 shows the correlation matrix between the students' science performance, mathematical ability and level of science misconceptions. Considering students' science performance, data revealed that their performance in science is significantly related to their mathematical ability $(\mathrm{r}=0.334, \mathrm{p}<0.01)$ and level of science misconceptions $(\mathrm{r}=1.000, \mathrm{p}<0.01)$.
Table 6 Correlation Matrix among Mathematical Ability, Level of Science Misconceptions and Science Performance

\begin{tabular}{lcccccc}
\hline $\begin{array}{l}\text { Level of } \\
\text { Science } \\
\text { Misconceptions }\end{array}$ & $\mathrm{N}$ & Mean & SD & $\mathrm{T}$ & $\mathrm{df}$ & Sig \\
\hline \hline Low & 25 & 30.08 & 1.115 & 9.162 & 69 & $0.000^{*}$ \\
$\begin{array}{l}(31.0-40.0) \\
\text { Moderately }\end{array}$ & 46 & 25.04 & 2.616 & & & \\
High/Low & & & & & & \\
$(21.0-30.0)$ & & & & & & \\
\end{tabular}

*Correlation is significant at the 0.01 level (2-tailed).

Therefore, the null hypothesis which states that there are no significant relationships among mathematical ability, level science misconceptions and performance, is hereby rejected.

\section{CONCLUSIONS AND RECOMMENDATIONS}

This study focused on the mathematical ability, level of science misconceptions and science performance of firstyear college students. Respondents of the study are mathematical "fairly able". It appears that the mathematical skills of students need improvement in analyzing problem information effectively. Some students are mathematical "highly able" problem solvers who can use a variety of techniques or strategies as they comprehend and represent a certain problem before they proceed to a solution. However, students who are "able" are well within the average level indicating that they acquire the basic skills in mathematics.

As found out, students have "low" science misconceptions indicating they have perceived some right notion, ideas, theories, and concepts in some areas of science but are still having some difficulty in assigning meaning to scientific concepts when applied to a certain situation.

Students have a "satisfactory" performance in science based on the secondary science curriculum. Students understood and applied the science concepts, performed scientific processes and skills, and demonstrated scientific attitudes and values.

Though science and mathematics are two related subjects, results show that they are significantly different. When students perform satisfactorily they can apply mathematical skills and concepts in science. But this is not a guarantee that students who perform well in mathematics will likely the same in science. As observed, some students are fast learners in mathematics but slow in understanding 
concepts in science. On the other hand, good mathematical skills may be an indicator of science performance.

The result that there is a significant difference in science performance of students when grouped according to their level of science misconceptions imply that identifying students' misconception gave teachers the basis for an instructional plan that could fit students' prior knowledge. Correcting science misconceptions may produce concrete and organized schemas and may lead to a better understanding of abstract science concepts.

As found out that there are significant relationships among science performance, mathematical ability, and level of science misconceptions, it appears that mathematical ability and level of science misconceptions are factors affecting science performance. If one possesses good mathematical skills together with a very low level of science misconceptions these may result in very satisfactory science performance. The connections of the three variables are related to one another. It is observed that mathematically able students are those with high success in pursuing science. If students acquired the correct ideas or concepts they may not only able to identify scientific concepts but able to relate, interpret and analyze scientific laws, principles and theories and apply these skills to daily living. Students will perform better in science if they are fully equipped with all the necessary competence and skills needed.

The students' mathematical ability was just 'fairly able'. For students to be mathematical 'highly able', teachers are encouraged to develop differentiated strategies or activities inside the classroom that can combat students' weaknesses in mathematics. Mathematics teachers should also encourage and develop the student's competence in the use of logical procedures in problem-solving, critical thinking, algebraic, and logical reasoning.

For students to eradicate their science misconceptions, they must be judicious in learning new concepts from different information sources. Students are encouraged to conduct scientific projects and investigations to challenge their scientific beliefs. Teachers should assess or identify students' common science misconceptions and specific strategies for changing them. To bridge the gaps from students' prior knowledge, teachers can assist learners by providing the kinds of information and experiences to cope up students' science misconceptions.

The 'satisfactory' science performance of the students may be improved to a 'very satisfactory' performance in science if the mathematical procedure in problem-solving is practiced with accuracy and precision. Problems of different variety and units should be practiced frequently. The science concepts behind the problems should be marked. Teachers, on the other hand, may formulate appropriate learning strategies for students who have difficulty in learning science, maintain students' attention, participation, and dynamic atmosphere in the class.

\section{REFERENCES}

[1] Bahar, M. (2003). Misconceptions in biology education and conceptual change strategies. Educ. Sci. Theory Pract. 3: 55-64.

[2] Bock, R. (2015) First grade math skills set foundation for later math ability. National Institutes of Health (NIH). https://www.nih.gov/news-events/news-releases/first-grademath-skills-set-foundation-later-math-ability

[3] Bruner, J. (1960) Constructivism and Discovery Learning. http://tip.pscychology.org.

[4] Cardak, O. (2009). Science Students' Misconceptions of the Water Cycle According to their Drawings. Journal of Applied Sciences, 9(5), 865-873. https://doi.org/10.3923/jas.2009.865.873

[5] Cardak, O., \& Dikmenli, M. (2016). Student Science Teachers' Ideas about the Degradation of Ecosystems. International Education Studies, 9(3), 95. https://doi.org/10.5539/ies.v9n3p95

[6] Crisostomo, S. (2000) Filipino Students' Still Rate Low in Math and Science. https://www.google.com.ph/url?sa=t\&rct=j\&q=\&esrc=s\&so urce $=$ web $\& c d=1 \& c a d=$ rja $\&$ uact $=8 \&$ ved $=2$ ahUKEwj58aCiJ_iAhVFyIsBHZgvDkIQFjAAegQIARAB\&url=https $\% 3$ A\%2F\%2Fwww.philstar.com\%2Fnewsfeature $\% 2 \mathrm{~F} 91528 \% 2 \mathrm{Ffilipino}-$ students-still-rate-low-math\&usg=AOvVaw251Ugc7eNOgTIzsVCAqC2

[7] Department of Education (2012). K to 12 Curriculum Guide Science-version.

[8] Deshmukh, N.D. \& Deshmukh, V.M. (2001) A Study of Students' Misconceptions in Biology of the Secondary School Level. KK College of Education, Mumbai \, India. Template PME28 (tifr.res.in)

[9] Eaton, J. F., Anderson, C. W., \& Smith, E. L. (1984). Students' Misconceptions Interfere with Science Learning: Case Studies of Fifth-Grade Students. The Elementary School Journal, 84(4), 365-379. https://doi.org/10.1086/461370

[10] Eggen, P., \& Kauchak, D. (2004) Educational Psychology: Windows, Classrooms. Upper Saddle River: Pearson Prentice Hall.

[11] Etkina, E. et al. (2006). Scientific abilities and their assessment. Physical Review Special Topics: Physics Education Research. 2. 10.1103/PhysRevSTPER.2.020103.

[12] Fisher \& Wandersee (2001). Mapping Biology Knowledge. Kluwer Academic Publishers in Education $5^{\text {th }}$ Edition, McGraw-Hill Companies, Inc.

[13] Gerberick, M. (2000) How Does Students' Prior Knowledge Affect Their Learning. https://prezi.com/duxuvrgs41vr/howdoes-students-prior-knowledge-affect-their-learning/

[14] Hanuscin, D. (2007) Misconceptions in Science E328: Elementary Methods. http://www.indiana.edu/ w505a/studwork/deborah/ 
[15] Heather, D. (2004). Physics Honors Thesis. pg.10-11) http://www.hu.edu.et/hu/index.php/academics/school-of graduate-studies/thesis-abstracts-2/96-school-of-educationand-training/218-factors-that-affect-academic-performanceof-female-students-in-science-subjects-the-case-of-selectedsecondary-schools Retrieved September 08,2013).

[16] Kambouri, M. (2007). Children's Misconceptions and A Look On How Teachers Respond to Them. Institute of Education, University of Warwick. https://warwick.ac.uk/alumni/services/eportfolios/edrhba/res earch/punlicationsmariakabouri/kabouri_paper1.doc

[17] Martin, D.J., Raynice, J.S., \& Schmidt, E. (2005). Process oriented-inquiry - a constructivist approach to early childhood science education: teaching teachers to do science. Journal of Elementary Science Education, 17(2), 13-26.

[18] Martin, R., Sexton, C. \& Gerlovich, J. (2002) Teaching Science for all Children: Methods for Constructing Understanding $2^{\text {nd }}$ Edition. Boston: Allyn and Bacon Publishing.

[19] Mirzaie, R A., Shahmohammadi, M., \& Kouhi, A., (2010) Study of students' mental images effect on learning chemistry. Eurasian J. Phys. Chem. Educ. 2(1): 53-62, 2010

[20] Norwich, B. (1987). Self-efficacy and mathematics achievement: A study of their relation. Journal of Educational Psychology, 79(4), 384-387. https://doi.org/10.1037/0022-0663.79.4.384

[21] Panes, L.M. (2006) High School Students' Difficulties in Solving Problems in Physics. http://pnupres.tripod.com/panes.html

[22] Performance of Philippine High Schools With Special Science Curriculum In The 2008 Trends in International Mathematics and Science Study (TIMMSAdvanced).http://www.nscb.gov.ph/ncs/11thNCS/papers/inv ited\%20papers/ips07/01_Performance\%20of\%20Philippine $\% 20$ High $\% 20$ Schools $\% 20 \mathrm{With} \% 20$ Special\%20Science $\% 20$ Curriculum $\% 20$ In $\% 20$ The $\% 202008 \% 20$ Trends\%20in\%20I nternational $\% 20$ Mathematics\%20and $\% 20$ Science $\% 20$ Study $\% 20$ (TIMMS-Advanced).pdf)

[23] Sadler, P. M., Sonnert, G., Coyle, H. P., Cook-Smith, N., \& Miller, J. L. (2013). The Influence of Teachers' Knowledge on Student Learning in Middle School Physical Science Classrooms. American Educational Research Journal, 50(5), $1020-1049$. https://doi.org/10.3102/0002831213477680

[24] Thompson, F., and Logue S., (2006). An Exploration of Common Student Misconceptions in Science. International Education Journal, 2006, 7 (4), 553-559. https://files.eric.ed.gov/fulltext/EJ854310.pdf 